\title{
Some Biological Aspects and Proline Metabolism Genes as Influenced by Polyethylene Glycol and Salicylic Aacid in Two Wheat Cultivars
}

Naglaa Loutfy

South Valley University

Ahmed Hassanein

Sohag University

Masahiro Inouhe

Ehime University

Jehan Salem ( $\sim$ hashsalem@yahoo.com )

Sohag University

\section{Research Article}

Keywords: Antioxidants, drought, proline metabolism genes, soluble sugars, salicylic acid, wheat

Posted Date: November 10th, 2021

DOl: https://doi.org/10.21203/rs.3.rs-966703/v1

License: (c) (i) This work is licensed under a Creative Commons Attribution 4.0 International License. Read Full License 


\section{Abstract}

The aim of this work was to study the response of two wheat cultivars with different drought tolerance to PEG (-0.4 Mpa) and SA (0.5 mM). Data of seed germination and seedling growth indicated that Misr-2 cultivar was more drought tolerant than Gemmeiza-12. Under non- stress conditions, Misr-2 had higher values of pigments, soluble sugars (Glu, Fru and Suc) and activities of antioxidant enzymes (CAT, APOX, GPOX and SOD) but lower values of proline than those of Gemmeiza-12. The cultivar with a higher proline content (Gemmeiza-12) compared to the other cultivar had a higher expression of proline synthesizing gene (P5CS) but lower expression of proline degrading genes (PDH and P5CDH). Under drought conditions, the drought-sensitive (Gemmeiza-12) needed more osmoregulators and antioxidants than drought-tolerant cultivar (Misr-2) to minimize the negative effects of water and associated oxidative stresses. Therefore, soluble sugars, proline content and anti-oxidation enzymes were higher in Gemmeiza12 than Misr-2. Also, under drought stress, up-regulation of P5CS and down-regulation of PDH and P5CDH in Gemmeiza-12 were higher than Misr-2. While treatment of the stressed plants with SA upregulated P5CS gene in both cultivars, down-regulation of PDH and P5CDH in Gemmeiza-12 was clearer than Misr-2.

\section{Introduction:}

Wheat (Triticum aestivum L.) is a popular crop in Egypt as well as all over the world. Drought is one of the most difficult threats to plant growth due to numerous adverse effects on biochemical, physiological and molecular mechanisms [1, 2]. Consequently, drought causes huge grain losses every year especially in the developing countries, where there is a population increases at high rates, the yield reduction average may be $50 \%$ or more [3]. Climate changes increase challenges with further losses in wheat yield. Therefore, selection of the more drought-tolerant line by screening the existed genotypes under created drought stress is an essential tool to attain food security worldwide.

Plants develop a variety protective mechanism that allows them to grow economically in the current harsh environment. These protective mechanisms include the accumulation of organic solutes (osmoprotectants), compatible solutes (such as proline and glycine betaine), modulate gene expression and control the obtained oxidative stress [4-7]. Proline accumulation in plants plays several protective roles including stability of cellular structures and enzymes, scavenging of reactive oxygen species (ROS) and hormonal balance $[5,6]$.

In comparing with normal conditions, drought significantly increased the activity of ascorbate peroxidase $(A P X)$, guaiacol peroxidase (POX) and phenylalanine ammonialyase (PAL), further increase in APX, POX, PAL and superoxide dismutase (SOD) activities was detected in water stressed wheat plants that treated with SA[8]. Under drought conditions, exogenously applied SA increased growth, photosynthetic pigments, total soluble sugars, proline and yield [9]. Regulation of proline metabolism by SA is important pathway in promotion of plant resistance to osmotic stress $[4,10]$. 
ROS accumulation (mainly $\mathrm{H}_{2} \mathrm{O}_{2}$ ) is associated directly or indirectly with regulation of proline biosynthesis $[5,11]$. In plants, proline is synthesized through orinithine and glutamate pathways. The last pathway is the main source of proline accumulation in abiotic stressed plants. [12] reported that pyrroline-5-carboxylate synthetase (P5CS1 and 2) converts glutamate to glutamic semialdehyde (GSA) and spontaneously to pyrroline-5-carboxylate (P5C), which is converted to proline by pyrroline-5carboxylate reductase (P5CR). P5CS is encoded by two genes in most plant species, but P5CR is encoded by one gene [13]. On the other hand, proline catabolism is catalyzed by proline dehydrogenase (PDH) which convert proline to P5C. Then, P5C is catalyzed by P5C dehydrogenase (P5CDH) to glutamate [12]. $\mathrm{PDH}$ is encoded by two genes, whereas P5CDH is encoded by one gene [14]. While PDH transcription is activated during rehydration periods, it is repressed by dehydration to retard proline degradation leading to proline accumulation during stress periods [15].

Polyethylene glycol (PEG) was chosen to induce drought stress, where it exerts drought response as similar as nature, where it does not penetrate into plant body but reduces water availability [16]. The decrease in $\Psi_{\mathrm{W}}$ due to PEG was associated with accumulation of ROS and enhanced proline synthesis due to enhance the expression of proline synthesis genes; P5CS and P5CR [5].

Seed germination and seedling growth parameters are influenced by stress intensity and genetic background $[17,18]$. Expressed drought tolerance during in vitro seed germination is strongly correlated to that of field conditions [19]. This study aimed to estimate the response of two wheat cultivars to PEGinduced drought stress at early growth stage. The effects of PEG stress were evaluated on the basis of crosslink between some related physiological aspects, expression of proline metabolism genes in relation and growth of two wheat cultivars differ in drought tolerance and treated with SA.

\section{Materials And Methods:}

\section{Plant material and growth conditions}

Seeds of two wheat (Triticum aestivum $L$ ) cultivars (Misr-2 and Gemmeiza-12) were obtained from Wheat Research Department, Agricultural Research Centre, Giza, Egypt. Misr-2 cultivar was chosen from materials introduced from CIMMYT (International Maize and Wheat Improvement Center in Mexico) with the name of "2nd EBWYT 2006/2007" to Wheat Research Department (WRD), Field Crops Research Institute (FCRI) at Agricultural Research Center (ARC), Egypt. Pedigree and selection history of the cultivar Misr-2 are SKAUZ/BAV92 (CMSS96M03611S-1M-0105Y-010M-010SY-8M-OY-OS). Wheat cultivar Gemmeiza-12 was elected from CIMMYT materials grown at El- Gemmeiza Agricultural Research Station, ARC. in 2005/2006 season. The cross name and pedigree of the cultivar Gemmeiza-12 are OTUS/3/SARA/THB//VEE (CMSS97Y00227 S-5Y-010M-010Y-010M-2Y - 1M-0Y- OGM).

Seeds were sterilized with sodium hypochlorite solution (5\%) for five minutes, washed thoroughly with sterilized distilled water. To determine the recommended concentration of PEG, nutrient solutions [0.5 strength Hoagland's [20] supplemented with different concentrations of polyethylene glycol $6000(0.0$, 
$-0.1 \mathrm{MPa},-0.2 \mathrm{MPa},-0.3 \mathrm{mPa},-0.4 \mathrm{MPa}$ or $-0.5 \mathrm{MPa}$ ) were used. Seeds were germinated on Whatman filter paper in Petri dishes containing nutrient solutions under lab conditions for seven days.

To determine the effect of PEG and SA, sterilized seeds were divided into two groups. While, the first group was soaked in distilled water (control), the second group was soaked in $0.5 \mathrm{mM} \mathrm{SA}$ for $12 \mathrm{hrs}$. Nutrient solutions were renewed every two days. Osmotic potentials of PEG 6000 were calculated as described by [21]. Germinated seeds were left to continue seedling growth in nutrient solutions with or without PEG or SA for two weeks. Triplicates samples were used for each treatment, 15 seeds each. Then, seedlings were harvested, washed three times with double distilled water. Root and shoot growth parameters were determined and quickly frozen at $-20^{\circ} \mathrm{C}$ for further biochemical investigation.

\section{Determination of photosynthetic pigments}

According to [22], photosynthetic pigments (chlorophyll a, b and carotenoids) were extracted from fresh leaves and determined, and total photosynthetic pigments were calculated. Four observations over three replications for each treatment were recorded and presented as an average.

\section{Determinations of soluble sugars using high performance liquid chromatography (HPLC):}

For determination of soluble sugars, frozen plant tissues of two wheat cultivars were extracted using $80 \%$ ethanol $\left(1 \mathrm{ml} / \mathrm{g} \mathrm{FM}^{-1}\right)$ at $80^{\circ} \mathrm{C}$ for $30 \mathrm{~min}$. Extracts were incubated at $0{ }^{\circ} \mathrm{C}$ for $30 \mathrm{~min}$ and centrifuged at $10,000 \mathrm{~g}$ for $5 \mathrm{~min}$. The supernatants were dried in vacuum at $50^{\circ} \mathrm{C}$ and dissolved in $50 \%$ acetonitrile. The obtained impurities were removed by filtration (Millipore Millex-GV, pore size $0.22 \mu \mathrm{m}$ ). Samples (20 $\mu \mathrm{l})$ were injected into a carbohydrate analysis column (Shodex NH2P-504E, $250 \mathrm{~mm} \times 4.6 \mathrm{~mm}$ i.d., Showa Denko, Tokyo, Japan) of HPLC pump (L-7000, Hitachi, Tokyo). Columns were eluted with $75 \%$ acetonitrile $(\mathrm{v} / \mathrm{v})$ at a flow rate of $0.5 \mathrm{ml} \mathrm{min}^{-1}$. Monosaccharides and oligosaccharides were determined with a refractive index (RI) detector (L7490, Hitachi) equipped with a chromatographic data processor (D-2500, Hitachi).

\section{Assays of enzymes activities}

Catalase (EC 1.11.1.6) activity was estimated spectrophotometrically [23]. CAT activity was estimated by the decrease in absorbance at $240 \mathrm{~nm}$ for $1 \mathrm{~min}$ due to consuming of $\mathrm{H}_{2} \mathrm{O}_{2}\left(E=0.036 \mathrm{mM} \mathrm{cm}^{-1}\right)$. The prepared reaction mixture consisted of $50 \mathrm{mM}$ phosphate buffer containing $0.1 \mu \mathrm{M}$ EDTA, $20 \mathrm{mM} \mathrm{H}_{2} \mathrm{O}_{2}$ $(\mathrm{pH} 7.0)$ and $0.05 \mathrm{ml}$ enzyme extract. One CAT unit means the amount of enzyme necessary to decompose $1 \mu \mathrm{mol} \mathrm{min}^{-1} \mathrm{H}_{2} \mathrm{O}_{2}$. 
POX (EC 1.11.1.7) activity was estimated as described by [24]. Assay mixture was prepared to contain 50 $\mathrm{mM}$ potassium phosphate buffer [( $\mathrm{pH}$ 6.8), $0.1 \mathrm{mM}$ EDTA, $5 \mathrm{mM}$ guaiacol and $\left.0.3 \mathrm{mM} \mathrm{H}_{2} \mathrm{O}_{2}(30 \%)\right]$.

Absorbance increase due to oxidation of guaiacol $\left(E=26.2 \mathrm{mMcm}^{-1}\right)$ was measured spectrophotometrically at $470 \mathrm{~nm}$. Then, POX activity was calculated in terms of $\mu \mathrm{M}$ of guaiacol oxidized $\mathrm{min}^{-1} \mathrm{~g}^{-1}$ fresh weight at $25 \pm 2{ }^{\circ} \mathrm{C}$.

APX (EC 1.11.1.11) activity was estimated according to [25]. Reaction mixture contained $50 \mathrm{mM}$ phosphate buffer containing $0.5 \mathrm{mM}$ EDTA, $0.5 \mathrm{mM}$ ascorbate, $0.1 \mathrm{mM} \mathrm{H}_{2} \mathrm{O}_{2}$ and $0.05 \mathrm{ml}$ enzyme extract $(\mathrm{pH}$ 7.0). The decrease in ascorbate concentration was associated with decline in absorbance at $290 \mathrm{~nm}$ for $1 \mathrm{~min}$. Activity was calculated using the extinction coefficient $\left(E=2.8 \mathrm{mM} \mathrm{cm}^{-1}\right)$ for ascorbate.

SOD (EC 1.15.1.1) activity was estimated as described by [26]. SOD activity was assayed due to its ability to inhibit the photochemical reduction of nitrobluetetrazolium (NBT). The reaction mixture consisted of $50 \mathrm{mM}$ sodium phosphate buffer containing $13 \mathrm{mM}$ methionine, $2 \mathrm{mM}$ riboflavin, $75 \mathrm{mM}$ NBT, $100 \mathrm{mM}$ EDTA ( $\mathrm{pH} 7.8$ ) and $0.05 \mathrm{~mL}$ enzyme extract. The production of blue formazan was followed by the increase in absorbance at $560 \mathrm{~nm}$. The unit of SOD activity was the amount of enzyme that inhibits the nitrobluetetrazolium photoreduction (Extinction factor $(E)=10.3 \mathrm{mM} \mathrm{cm}^{-1}$ ).

\section{Proline determination:}

Free proline contents were determined according to [27]. Briefly, $100 \mathrm{mg}$ of powdered tissue was homogenized in $10 \mathrm{ml}$ of $3 \%$ SSA for $10 \mathrm{~min}$ followed by filtration. Two $\mathrm{ml}$ of the filtrate were mixed with $2 \mathrm{ml}$ of glacial acetic acid and $2 \mathrm{ml}$ of acid ninhydrin for $1 \mathrm{~h}$ at $90^{\circ} \mathrm{C}$. The developed color was extracted in $4 \mathrm{ml}$ toluene and measured colorimetrically at $520 \mathrm{~nm}$ against toluene. Final calculations were performed using a proline standard curve. The results were introduced as the average of three replicates for each treatment.

\section{Semiquantitative RT-PCR:}

According to the manufacture's instruction, RNA was isolated from plants grown under different conditions by using RNAiso (TaKaRa, shiga Japan). RNA quality was investigated by electrophoresis using $1 \%$ agarose gel containing ethidium bromide and its concentration was determined spectrophotometrically. The isolated RNA was heated for $1 \mathrm{~min}$ at $65^{\circ} \mathrm{C}$ and stored in ice. Reverse transcription was fulfilled by high capacity cDNA reverse transcription (Applied biosynthesis Japan) in a $20 \mu \mathrm{L}$ reaction with $1 \mu \mathrm{g}$ total RNA, 25x dNTPs, $10 x$ reverse transcription buffer, $10 x$ random primers and $(50 \mathrm{U} / \mu \mathrm{l})$ reverse transcriptase (MD, USA). The reaction mixtures were incubated for $10 \mathrm{~min}$ at $25^{\circ} \mathrm{C}, 120$ min at $37^{\circ} \mathrm{C}, 5 \mathrm{sec}$ at $85^{\circ} \mathrm{C}$ and then at $4{ }^{\circ} \mathrm{C}$. TE buffer ( $1 \mathrm{M}$ Tris PH 8, 0.5 M EDTA, MilliQ $\mathrm{H}_{2} \mathrm{O}$ ) was used to dilute the cDNA solution $(100 \mu \mathrm{L})$. PCR reaction was performed using 30 cycles; each cycle was $98^{\circ} \mathrm{C}$ for $10 \mathrm{sec}, 55^{\circ} \mathrm{C}$ for $30 \mathrm{sec}$ and $72{ }^{\circ} \mathrm{C}$ for $1 \mathrm{~min}$ in a reaction mixture containing $2.5 \mathrm{mM}$ dNTPs, $10 \mathrm{x}$ EX 
Taq Buffer and TaKaRa Ex Taq HS 0.25 units and 0.5 pmol primers. Specific primers were used for P5CS detection (TaP5CS 1468-1487F GCTCTAGCAATCCGAAGTGG; and TaP5CS 1569-1550R, TGGAATCACGCTGGTTATGA), P5CDH (TaP5CDH 713-732F, TGATCAGGTTGCTTCACGAG; and TaP5CDH 935-916R, GTGAGCTCCCAGTGAAGAGG) and ProDH (TaProDH 1284-1303f GAGCAAGTACCTGCCCTACG and TaProDH 1427-1408R GCGTTCTTGAACCTCCTGAC). As a positive control, actin RT-PCR was used for all RT-PCR reactions. Specific primers were also used where forward primer was wheat actin $F$ (GCCACACTGTTCCAATCTATGA); and wheat actin R as reverse (GCGGTTGTTGTGAGGGAGTA). Products of the PCR reaction were visualized using electrophoresis on a TBE $(0.89 \mathrm{M}$ Tris, $0.89 \mathrm{M}$ boric acid, $0.02 \mathrm{M}$ EDTA) and $1 \%$ agarose gel containing $0.5 \mathrm{mg} / \mathrm{ml}$ ethidium bromide.

\section{Statistical analysis:}

Experiments were planned in completely random design and data were statistically analyzed using standard deviation (SD) as depicted by [28]. All data were subjected to the analyses of variance (ANOVA) to test the significant difference between the mean $(n=3)$ of measured variables

\section{Results:}

Under unstressed conditions, the percentage of germination was $100 \%$ for the two wheat cultivars by the fourth day (Table 1). By decreasing the water potential using PEG (less than -1 Mpa), there was a difference in the ability of the two cultivars to germinate, this difference increased by decreasing the water potential up to $-0.4 \mathrm{Mpa}$, where the percentage of germination was $80 \%$ and $30 \%$ for Misr- 2 and Gemmeiza-12, respectively. Under application of PEG with water potential of $-5 \mathrm{Mpa}, 55 \%$ of Misr-2 seeds were germinated by the seventh day but seeds of Gemmeiza-12 did not germinate at all. 
Table 1

Effect of water stress (Mpa) potential on seed germination for 7 days.

\begin{tabular}{|c|c|c|c|c|c|c|}
\hline \multirow[t]{3}{*}{ Day } & \multicolumn{6}{|c|}{$\%$ percentage of germination } \\
\hline & Control & $-0.1 \mathrm{Mpa}$ & $-0.2 \mathrm{Mpa}$ & $-0.3 \mathrm{Mpa}$ & $-0.4 \mathrm{Mpa}$ & $-0.5 \mathrm{Mpa}$ \\
\hline & & & \multicolumn{4}{|l|}{ Misr-2 } \\
\hline 1 & 64 & 59 & 55 & 50 & 42 & 28 \\
\hline 2 & 90 & 80 & 76 & 70 & 51 & 38 \\
\hline 3 & 100 & 93 & 80 & 78 & 60 & 44 \\
\hline 4 & 100 & 100 & 86 & 85 & 73 & 50 \\
\hline 5 & 100 & 100 & 90 & 90 & 80 & 55 \\
\hline 6 & 100 & 100 & 98 & 90 & 80 & 55 \\
\hline 7 & 100 & 100 & 98 & 90 & 80 & 55 \\
\hline \multicolumn{7}{|c|}{ Gemmeiza-12 } \\
\hline 1 & 70 & 52 & 42 & 35 & 13 & 0 \\
\hline 2 & 90 & 69 & 52 & 43 & 20 & 0 \\
\hline 3 & 95 & 85 & 60 & 50 & 24 & 0 \\
\hline 4 & 100 & 96 & 68 & 63 & 30 & 0 \\
\hline 5 & 100 & 100 & 78 & 68 & 30 & 0 \\
\hline 6 & 100 & 100 & 88 & 70 & 30 & 0 \\
\hline 7 & 100 & 100 & 90 & 70 & 30 & 0 \\
\hline
\end{tabular}

When seed germination of the two cultivars was taken place in the nutrient solution containing PEG (-0.4 Mpa), seedling fresh and dry weights of the two cultivars decreased (Table 2), decrease in seedling fresh weight was lower in Misr-2 (32.0\%) than that of Gemmeiza-12 (41.4\%). This decrease in seedling fresh weight was improved when plants were treated with SA, where reduction in fresh weights was $13.0 \%$ and 20.8\% for Misr-2 and Gimaza-12, respectively. Also, shoot length decreased under PEG and ranged from $24.6 \%$ (Gemmeiza-12) to $27.4 \%$ (Misr-2). Compared to plants treated only with PEG, the decrease in shoot length was improved using SA, where the reduction in shoot length became $11 \%$ in both cultivars. On the contrary, the root length increased when plants were exposed to PEG regardless of the presence or absence of SA. When combination between PEG and SA was used, the increase in root length of Misr-2 (104.1\%) was higher than that of Gimaza-12 (89.7\%). 
Table 2

Effects of salicylic acid $(0.5 \mathrm{mM})$ and water stress PEG (-0.4Mpa) and SA $(0.5 \mathrm{mM})$ on fresh mass and dry mass of 15-day old seedlings of two wheat cultivars.

\begin{tabular}{|c|c|c|c|c|c|c|}
\hline \multirow[t]{4}{*}{ Treatment } & \multicolumn{3}{|l|}{ Shoot } & \multicolumn{3}{|l|}{ Root } \\
\hline & FM & DM & Length & FM & DM & Length (cm) \\
\hline & (g) & (g) & & (g) & (g) & \\
\hline & \multicolumn{6}{|l|}{ Misr-2 } \\
\hline Control & $\begin{array}{l}0.753 \pm \\
0.006^{b}\end{array}$ & $\begin{array}{l}0.089 \pm \\
0.003^{b}\end{array}$ & $25 \pm 0.5^{\mathrm{b}}$ & $\begin{array}{l}0.250 \pm \\
0.005^{\mathrm{b}}\end{array}$ & $\begin{array}{l}0.026 \pm \\
0.004^{b}\end{array}$ & $\begin{array}{l}7.35 \pm \\
0.30^{d}\end{array}$ \\
\hline PEG & $\begin{array}{l}0.550 \pm \\
0.004^{d}\end{array}$ & $\begin{array}{l}0.076 \pm \\
0.001^{c}\end{array}$ & $18.16 \pm 0.57^{d}$ & $\begin{array}{l}0.132 \pm \\
0.002^{d}\end{array}$ & $\begin{array}{l}0.016 \pm \\
0.004^{c}\end{array}$ & $\begin{array}{l}12 \pm \\
0.005^{b}\end{array}$ \\
\hline SA & $\begin{array}{l}0.887 \pm \\
0.006^{a}\end{array}$ & $\begin{array}{l}0.095 \pm \\
0.002^{a}\end{array}$ & $30.66 \pm 0.53^{a}$ & $\begin{array}{l}0.295 \pm \\
0.005^{a}\end{array}$ & $\begin{array}{l}0.032 \pm \\
0.005^{a}\end{array}$ & $\begin{array}{l}8.83 \pm \\
0.28^{c}\end{array}$ \\
\hline SA+PEG & $\begin{array}{l}0.679 \pm \\
0.002^{\mathrm{c}}\end{array}$ & $\begin{array}{l}0.069 \pm \\
0.001^{c}\end{array}$ & $22.33 \pm 0.56^{c}$ & $\begin{array}{l}0.194 \pm \\
0.004^{\mathrm{C}}\end{array}$ & $\begin{array}{l}0.025 \pm \\
0.005^{b}\end{array}$ & $\begin{array}{l}15 \pm \\
0.005^{a}\end{array}$ \\
\hline \multicolumn{7}{|c|}{ Gemmeiza-12 } \\
\hline Control & $\begin{array}{l}0.492 \pm \\
0.007^{\mathrm{b}}\end{array}$ & $\begin{array}{l}0.058 \pm \\
0.004^{b}\end{array}$ & $19.66 \pm 0.76^{b}$ & $\begin{array}{l}0.139 \pm \\
0.001^{b}\end{array}$ & $\begin{array}{l}0.019 \pm \\
0.002^{b}\end{array}$ & $6.5 \pm 0.5^{d}$ \\
\hline PEG & $\begin{array}{l}0.293 \pm \\
0.005^{d}\end{array}$ & $\begin{array}{l}0.042 \pm \\
0.001^{d}\end{array}$ & $14.83 \pm 0.76^{d}$ & $\begin{array}{l}0.077 \pm \\
0.003^{d}\end{array}$ & $\begin{array}{l}0.013 \pm \\
0.001^{\mathrm{c}}\end{array}$ & $\begin{array}{l}10.33 \pm \\
0.57^{b}\end{array}$ \\
\hline SA & $\begin{array}{l}0.586 \pm \\
0.004^{\mathrm{a}}\end{array}$ & $\begin{array}{l}0.071 \pm \\
0.002^{\mathrm{a}}\end{array}$ & $22.83 \pm 0.28^{a}$ & $\begin{array}{l}0.174 \pm \\
0.005^{a}\end{array}$ & $\begin{array}{l}0.027 \pm \\
0.004^{\mathrm{a}}\end{array}$ & $7.5 \pm 0.5^{c}$ \\
\hline SA+PEG & $\begin{array}{l}0.386 \pm \\
0.006^{\mathrm{c}}\end{array}$ & $\begin{array}{l}0.049 \pm \\
0.001^{c}\end{array}$ & $17.5 \pm 0.5^{c}$ & $\begin{array}{l}0.114 \pm \\
0.003^{c}\end{array}$ & $\begin{array}{l}0.017 \pm \\
0.005^{b}\end{array}$ & $\begin{array}{l}12.33 \pm \\
0.57^{a}\end{array}$ \\
\hline
\end{tabular}

Pigment content (chl-a, chl-b and carotenoides) expressed in $\mathrm{mg} / \mathrm{g}^{-1} \mathrm{~F} . \mathrm{w}$ under control or PEG stress in Misr-2 was higher than that of Gemmeiza-12 (Table 3). Compared with the control, the concentration of chlorophyll a, chlorophyll b and carotenoids (total pigments) decreased significantly when plants of two cultivars were subjected to PEG stress, reduction in total pigment content of Gemmeiza-12 (26.2\%) was higher than that of Misr-2 (20.8\%). The recorded decrease in the concentration of these pigments due to PEG was improved when plants were treated with SA [Gimaza-12 (10.7\%) and Mis-2 (9.1\%)]. The negative effect of PEG stress on carotenoid concentration was completely avoided by using SA. 
Table 3

Effects of salicylic acid ( $0.5 \mathrm{mM})$ and water stress ((-0.4Mpa) on leaf chlorophyll and carotenoid contents of 15 -day old seedlings of two wheat cultivars.

\begin{tabular}{|c|c|c|c|c|}
\hline \multirow[t]{2}{*}{ Treatment } & Chl a & $C h l b$ & Carotenoid & Total pigment \\
\hline & \multicolumn{4}{|l|}{ Misr-2 } \\
\hline Control & $1.745 \pm 0.011^{\mathrm{b}}$ & $0.630 \pm 0.004^{b}$ & $0.490 \pm 0.005^{b}$ & $2.865^{\mathrm{b}}$ \\
\hline PEG & $1.385 \pm 0.007^{d}$ & $0.490 \pm 0.006^{d}$ & $0.395 \pm 0.003^{d}$ & $2.27^{d}$ \\
\hline SA & $1.887 \pm 0.007^{a}$ & $0.681 \pm 0.005^{a}$ & $0.534 \pm 0.002^{\mathrm{a}}$ & $3.102^{\mathrm{a}}$ \\
\hline SA+PEG & $1.570 \pm 0.006^{c}$ & $0.545 \pm 0.003^{c}$ & $0.489 \pm 0.002^{c}$ & $2.604^{c}$ \\
\hline \multicolumn{5}{|c|}{ Gemmeiza-12 } \\
\hline Control & $1.504 \pm 0.004^{b}$ & $0.543 \pm 0.005^{b}$ & $0.431 \pm 0.002^{b}$ & $2.478^{b}$ \\
\hline PEG & $1.112 \pm 0.007^{d}$ & $0.358 \pm 0.001^{d}$ & $0.358 \pm 0.003^{c}$ & $1.828^{\mathrm{d}}$ \\
\hline SA & $1.795 \pm 0.011^{a}$ & $0.560 \pm 0.006^{\mathrm{a}}$ & $0.512 \pm 0.006^{\mathrm{a}}$ & $2.867^{a}$ \\
\hline SA+PEG & $1.337 \pm 0.005^{c}$ & $0.455 \pm 0.001^{c}$ & $0.422 \pm 0.003^{b}$ & $2.214^{c}$ \\
\hline \multicolumn{5}{|c|}{${ }^{*}$ The values of Photosynthetic pigment contents are expressed as $\mathrm{mg} \mathrm{g}^{-1}$ fresh weight. } \\
\hline \multicolumn{5}{|c|}{ Values not followed by the same letter are significantly different at $P<0.05$. } \\
\hline
\end{tabular}

Misr-2 cultivar accumulated total soluble sugars (glucose, fructose and sucrose) under control (66.53 $\mathrm{mg} / \mathrm{g}^{-1}$ F.w.) or PEG stress (127.08 mg/ $\mathrm{g}^{-1}$ F.w.) more than those of Gimaza-12 under control condition (35.79 mg/ $\mathrm{g}^{-1}$ F.w.) and PEG stress $\left(70.76 \mathrm{mg} / \mathrm{g}^{-1}\right.$ F.w.) (Table 4). The highest increase in the concentration of each sugar was recorded when plants were subjected to water stress and treated with $\mathrm{SA}$, where the increase in glucose, fructose and sucrose contents (compared to control) for Gemmeiza-12 were $115.8 \%, 244.0 \%$ and $179.0 \%$, while for Misr- 2 were $133.7 \%, 226.1 \%$ and $114.4 \%$, respectively. These results also indicated that the highest percentage of increases was recorded for fructose sugar. In comparison to that of control, the mean percentage of increase in the three sugars of water-stressed Gemmeiza-12 plants treated with SA (97.7\%) was higher than that of Misr-2 (91.0\%). 
Table 4

Effects of salicylic acid $(0.5 \mathrm{mM})$ and water stress $(-0.4 \mathrm{Mpa})$ on contents of soluble sugars of two wheat cultivars.

\begin{tabular}{|lllll|}
\hline Treatment & Glu & Fru & Suc & Total sugars \\
\cline { 2 - 5 } & Misr-2 & & \\
\hline Control & $34.77 \pm 0.33^{\mathrm{d}}$ & $13.05 \pm 0.6^{\mathrm{d}}$ & $18.71 \pm 0.16^{\mathrm{d}}$ & $66.53^{\mathrm{d}}$ \\
\hline PEG & $62.78 \pm 0.96^{\mathrm{b}}$ & $33.22 \pm 0.11^{\mathrm{b}}$ & $31.08 \pm 0.12^{\mathrm{b}}$ & $127.08^{\mathrm{b}}$ \\
\hline SA & $49.92 \pm 0.22^{\mathrm{c}}$ & $19.40 \pm 0.34^{\mathrm{c}}$ & $24.17 \pm 0.15^{\mathrm{c}}$ & $93.49^{\mathrm{c}}$ \\
\hline SA+PEG & $81.25 \pm 0.45^{\mathrm{a}}$ & $42.55 \pm 0.28^{\mathrm{a}}$ & $40.12 \pm 0.15^{\mathrm{a}}$ & $163.92^{\mathrm{a}}$ \\
\hline Gemmeiza-12 & & & & \\
\hline Control & $18.12 \pm 0.11^{\mathrm{d}}$ & $7.55 \pm 0.12^{\mathrm{d}}$ & $10.12 \pm 0.06^{\mathrm{d}}$ & $35.79^{\mathrm{d}}$ \\
\hline PEG & $31.44 \pm 0.27^{\mathrm{b}}$ & $19.11 \pm 0.11^{\mathrm{b}}$ & $20.21 \pm 0.11^{\mathrm{b}}$ & $70.76^{\mathrm{b}}$ \\
\hline SA & $23.22 \pm 0.08^{\mathrm{c}}$ & $11.21 \pm 0.14^{\mathrm{c}}$ & $14.15 \pm 0.07^{\mathrm{c}}$ & $48.58^{\mathrm{c}}$ \\
\hline SA+PEG & $39.11 \pm 0.07^{\mathrm{a}}$ & $25.97 \pm 0.21^{\mathrm{a}}$ & $28.24 \pm 0.08^{\mathrm{a}}$ & $93.32^{\mathrm{a}}$ \\
\hline Glc, glucose; Fru, fructose; Suc, sucrose. The values are expressed as mg g ${ }^{-1}$ fresh weight. $^{\mathrm{a}}$ & & & & \\
\hline Values not followed by the same letter are significantly different at $\mathrm{P}<0.05$
\end{tabular}

The effect of PEG and SA on the activity of antioxidant enzymes (CAT, APX, POX and SOD) of two wheat cultivars were shown in Table 5. The activities of CAT, APX, POX and SOD under control or PEG tress conditions in Misr-2 were higher than those of Gemmeiza-12. Compared with the control, the increases in the activities of enzyme CAT (68.2\%), APX (138.3\%), POX (72.6\%) and SOD (116.4\%) of Gimaza-12 under the influence of PEG were higher than those of Misr-2 cultivar, where they were $27.7 \%, 116.3 \%, 60.9 \%$ and $77.3 \%$, respectively. Further increase in activities of three enzymes (APX, POX and SOD) was detected when stressed plants were treated with SA, the estimated values for Gimaza-12 were higher than those of Misr-2. Catalase activity decreased in Gemmeiza-12 under the influence of PEG with or without SA, but it increased significantly in Misr-2 under the same conditions. 
Table 5

Effects of salicylic acid $(0.5 \mathrm{mM})$ and water stress $(-0.4 \mathrm{Mpa})$ on the activities of four enzymes involved in anti-oxidation systems of two wheat cultivars.

\begin{tabular}{|c|c|c|c|c|}
\hline \multirow[t]{2}{*}{ Treatment } & CAT & APX & POX & SOD \\
\hline & \multicolumn{4}{|l|}{ Misr-2 } \\
\hline Control & $63.00 \pm 0.27^{b}$ & $41.92 \pm 0.22^{d}$ & $55.71 \pm 0.55^{d}$ & $46.42 \pm 0.22^{d}$ \\
\hline PEG & $80.48 \pm 0.55^{a}$ & $90.68 \pm 0.39^{b}$ & $89.61 \pm 0.39^{b}$ & $82.31 \pm 0.36^{b}$ \\
\hline SA & $72.84 \pm 0.29^{d}$ & $73.06 \pm 0.36^{c}$ & $76.00 \pm 0.11^{c}$ & $54.62 \pm 0.45^{c}$ \\
\hline \multirow[t]{2}{*}{$\mathrm{PEG}+\mathrm{SA}$} & $95.42 \pm 0.49^{c}$ & $119.67 \pm 0.33^{a}$ & $110.26 \pm 0.29^{a}$ & $112.78 \pm 0.87^{a}$ \\
\hline & \multicolumn{4}{|l|}{ Gemmeiza-12 } \\
\hline Control & $45.19 \pm 0.22^{b}$ & $25.67 \pm 0.45^{d}$ & $42.78 \pm 0.33^{d}$ & $33.42 \pm 0.65^{d}$ \\
\hline PEG & $76.01 \pm 0.51^{\mathrm{a}}$ & $61.18 \pm 0.30^{b}$ & $73.85 \pm 0.68^{b}$ & $72.31 \pm 0.29^{b}$ \\
\hline SA & $36.57 \pm 0.69^{c}$ & $42.21 \pm 0.34^{c}$ & $63.96 \pm 0.83^{c}$ & $44.62 \pm 0.34^{c}$ \\
\hline$P E G+S A$ & $42.10 \pm 0.55^{b}$ & $83.14 \pm 0.72^{a}$ & $95.41 \pm 0.29^{a}$ & $90.78 \pm 0.72^{a}$ \\
\hline \multicolumn{5}{|c|}{$\begin{array}{l}{ }^{*} \text { The values of CAT, APX, POX and SOD are expressed as } \mu \mathrm{g} \mathrm{H}_{2} \mathrm{O}_{2} \min ^{-1} \mu \mathrm{g}^{-1} \text { protein, } \mu \mathrm{g} \text { ascorbate } \\
\min ^{-1} \mu \mathrm{g}^{-1} \text { protein, } \mu \mathrm{g} \text { guaiacol } \mathrm{min}^{-1} \mu \mathrm{g}^{-1} \text { protein and } \mathrm{Ug} \mathrm{FW} \text { respectively. }\end{array}$} \\
\hline
\end{tabular}

When seedlings were exposed to a nutrient medium containing PEG as stress factor, there was a significant increase in proline concentration in shoots and roots of both wheat cultivars. Proline content ( $\mathrm{mg} / \mathrm{g}^{-1}$ F.w.) of Misr-2 under control or PEG stress was lower than that of Gemmeiza-12 (Table 6). The increase in proline content of plant shoots (150.7\%) and roots (306.3\%) of Gemmeiza-12 were higher than those of shoots $(89.6 \%)$ and roots $(132.9 \%)$ of Misr-2. Compared to the control, SA resulted in a decrease in proline concentration in shoots and roots of both wheat cultivars. When nutrient medium was supplemented with PEG and SA, the increase in proline concentrations of shoots $(53.1 \%)$ and roots (203.9\%) of Gemmeiza-12 as well as roots of Misr-2 (44.7\%) were higher than those of the control but lower than those of plants exposed to PEG only. Proline concentration was not influenced in Misr-2 shoots when plants were exposed to PEG and SA together. 
Table 6

Effects of salicylic acid $(0.5 \mathrm{mM})$ and water stress $(-0.4 \mathrm{Mpa})$ on proline content of two wheat cultivars.

\begin{tabular}{|c|c|c|}
\hline Treatment & Shoot & Root \\
\hline \multicolumn{3}{|c|}{ Misr-2 } \\
\hline Control & $2.98 \pm 0.18^{\mathrm{c}}$ & $0.85 \pm 0.02^{c}$ \\
\hline PEG & $5.65 \pm 0.28^{\mathrm{a}}$ & $1.98 \pm 0.17^{\mathrm{a}}$ \\
\hline SA & $2.45 \pm 0.13^{d}$ & $0.76 \pm 0.02^{c}$ \\
\hline \multirow[t]{2}{*}{$P E G+S A$} & $2.98 \pm 0.23^{b}$ & $1.23 \pm 0.16^{\mathrm{b}}$ \\
\hline & \multicolumn{2}{|l|}{ Gemmeiza-12 } \\
\hline Control & $4.56 \pm 0.12^{\mathrm{c}}$ & $1.27 \pm 0.03^{\mathrm{c}}$ \\
\hline PEG & $11.43 \pm 0.10^{\mathrm{a}}$ & $5.16 \pm 0.08^{\mathrm{a}}$ \\
\hline SA & $2.89 \pm 0.08^{d}$ & $1.12 \pm 0.03^{d}$ \\
\hline $\mathrm{PEG}+\mathrm{SA}$ & $6.98 \pm 0.11^{b}$ & $3.86 \pm 0.10^{\mathrm{b}}$ \\
\hline \multicolumn{3}{|c|}{ The values of proline are represented as $\mathrm{mg} \mathrm{g}^{-1}$ fresh weight. } \\
\hline \multicolumn{3}{|c|}{ Values not followed by the same letter are significantly different at $P<0.05$. } \\
\hline
\end{tabular}

Figure 1 shows expression patterns of P5CS, ProDH and P5CDH genes in Misr-2 (Fig. 1A) and Gemmeiza12 (Fig. 1. B) cultivars under the influence of PEG and SA. In plant shoots and roots of Misr-2 (Fig. 1A), expression of P5CS gene was hardly detected when plants were grown under non-stress conditions (control) even with SA. Under the stressed conditions (PEG), expression of P5CS gene was up-regulated, further up-regulation of P5CS was detected in roots and shoots of stressed plants treated with SA. On the contrary, P5CS gene expression of Gemmeiza-12 was clearly up-regulated in roots and shoots of plants subjected to the applied conditions except shoots of plants subjected to SA. In general, P5CS expression in Misr-2 was lower than that of Gemmeiza-12. In addition, P5CS expression of roots was higher than that of shoots in both wheat cultivars.

In Misr-2, expression of ProDH and P5CDH gene was clearly up-regulated in roots and shoots regardless of the presence or absence of both PEG and SA. In Gamaza-12 cultivar, ProDH gene expression was not detected in shoots of unstressed plants with or without SA. While, expression of ProDH was scarcely observed in shoots and roots of plants subjected to PEG stress, further increase in ProDH expression was detected in plants subjected to PEG and SA. Under the unstressed conditions, P5CDH gene expression seemed to be slightly detected in plant shoots and roots, it was higher in plant roots than plant shoots. Gemmeiza-12 shoots under the influence of SA alone or in combination with PEG showed undetectable P5CDH expression. On the other side, Gemmeiza-12 roots showed slight expression of ProDH under non- 
stress conditions with or without SA, but its expression decreased in plants subjected to PEG alone or in combination with SA.

\section{Discussion:}

Seed germination potential was substantially influenced by stress intensity and genotype. Percentage of seed germination of Misr-2 (80\%) was higher than that of Gemmeiza-12 (30\%) under PEG water stress (-0.4 Mpa). At - 5 Mpa stress condition, Gemmeiza- 12 did not germinate at all while $55 \%$ of Misr- 2 seeds germinated by the seventh day. Seed germination values indicated that Misr-2 was more drought tolerant than Gemmeiza-12. Traits associated with seed germination and seedling growth were used to detect genetic variation between genotypes of a given plant for drought tolerance, and these measures were used as screening criteria for drought tolerance [29-31]. In faba bean, growth parameters of the vegetative phase were more appropriate than those of seed germination stage to evaluate salinity tolerance [17].

The superiority of Misr-2 over Gemmeiza-12 in the ability to tolerate drought was confirmed by studying seedling growth under PEG stress condition (-0.4 Mpa), where the decrease in seedling fresh weight of Misr-2 was lower (32.0\%) than that of Gemmeiza-12 (41.4\%). The decrease in seedling fresh weight was improved when stressed plants were treated with SA, where it was higher in drought sensitive $(20.8 \%)$ than drought tolerant (13.0\%). In addition, root and shoot elongation was regarded as essential parameters for estimation of drought tolerance [32]. The decrease in shoot length of Gemaz-12 was $24.7 \%$ but it was $27.4 \%$ in Misr-2. On the other hand, the root length increased when plants were exposed to PEG regardless the presence or absence of SA. Under drought stress, increase in root length of Misr-2 was (63.3\%) higher than that of Gemmeiza-12 (58.9\%). Proline is synthesized in leaves [33] and transported to roots to carry out osmotic regulation [34]. Under drought stress, proline in root tips was significantly higher than root base. Then, osmotic potentials differed within the over length of the root and could regulate root length and mass [35]. In our work, increase in root length of wheat tolerant cultivar was higher than sensitive cultivar under drought stress. Accumulation of proline due to upregulation of proline synthesizing genes such as P5CS and down-regulation of proline degrading genes such as ProDH and P5CDH supplies energy for plant growth, survival and ability of plants to tolerate the applied stress [36]. Data of growth parameters indicated that Misr-2 was more drought tolerant than Gemmeiza-12. Contrary to the results of this work, [37] used Misr- 2 as sensitive wheat cultivar. According to drought indices studies, Gemaza cultivars including Gemmeiza-12 were found to be sensitive for both drought and salinity stresses [37-39]. Gemmeiza-12 cultivar was recommended for cultivation under non-stressful environments [40].

While the pigment content, expressed in $\mathrm{mg} / \mathrm{g}$ F.w., under control or PEG stress in Misr-2 was higher than that of Gemmeiza-12, the decrease in total pigments (chlorophyll a, chlorophyll b and carotenoids) of Gemmeiza-12 (26.2\%) was higher than that of Misr-2 (20.8\%). Plant pigments have a proven effect on providing plants with sugars and energy, which are the two important elements for plant metabolism and growth. Consequently, the cultivar that keeps the concentration of pigments not much lower (Misr-2) than 
the control compared to the other cultivar (Gemmeiza-12), was more tolerant under the applied stress condition (-0.4 Mpa) and expressed higher growth values. On the other side, increase pigment content and photosynthetic activity led to increased ROS generation. It nictitated increase in proline as well as enzymatic and non-enzymatic antioxidants [41] In this work, carotenoid, which has non-enzymatic antioxidant effect, had a positive correlation with proline content as was reported by [36].

In chloroplast, products of light reaction (ATP and NADPH) are utilized to produce glucose, fructose and ultimately sucrose. ATP and NADPH crosslinked the electron transport in chloroplast with proline production in cytosol [12]. In both wheat cultivars, PEG and/or SA resulted in increasing the concentration of glucose, fructose and sucrose, the highest increase was recorded when PEG and SA were used together. The mean percentages of increase in the three sugars of Gemmeiza-12 (179.6\%) was higher than that of Misr-2 (151.4\%). This means that the role of soluble sugars to control osmotic potential, modulation of gene expression and controlling of photosynthetic activity as well as ROS balance in Gemmeiza-12 was higher than that of Misr-2, as was explained by [42]. In addition, accumulation of sucrose was associated with activation the expression of P5CS to accumulate proline [43].

Stomatal closure during drought stress decreased $\mathrm{CO}_{2}$ uptake and over-excitation of the reaction centers of photosystem II [44] leading to formation of ROS [45]. Therefore, the activity of antioxidant enzymes such as CAT, APX, POX and SOD enhanced and coincided with an increase in proline content [46]. Activities of all the tested enzymes increased when wheat cultivars were grown under PEG stress with or without SA treatment. Activities of SOD, CAT, APX and GR (Glutathione reductase) in wheat were increased under drought stress and correlated with drought tolerance [47]. Compared with the control, the increases in the activities of enzyme APX, POX and SOD of Gimaza-12 under the influence of PEG were higher than those of Misr-2. Plants used antioxidant enzymes to convert ROS to $\mathrm{H}_{2} \mathrm{O}_{2}$ and ultimately to $\mathrm{H}_{2} \mathrm{O}$ and $\mathrm{O}_{2}$. High transcription of P5CS gene to accumulate proline was observed in rice treated with $\mathrm{H}_{2} \mathrm{O}_{2}$ [48]. Further increase in activities of these three enzymes was detected when plants were cultured in medium containing PEG and SA, where the estimated values of Gimaza-12 were higher than those of Misr-2. Mitigation the adverse effects of drought by SA may be due to improving the non-enzymatic antioxidants such as carotenoids and enzymatic antioxidants such as CAT, APX, SOD, POD, GR [5, 49, 50, 51]. Application of SA decreased catalase activity in Gemmeiza-12 even with PEG, while it increased significantly in Misr-2. Inhibition of CAT and APX by SA was previously reported [51].

To date, the role of accumulated proline on drought-stressed plants is controversial, where the correlation between increase in proline content and drought-tolerance is unclear [52]. There are two opinions, the first one indicates that accumulated proline enhances salt- or drought-tolerance of the plant. The second opinion contrasts the first one and suggests that proline accumulation results as a symptom of stress injury rather than an indicator of stress tolerance within plant species [52]. In our work, shoots and roots of wheat cultivars exposed to PEG showed a significant increase in proline content, it may be due to inhibition of protein synthesis, decrease proline utilization or degradation, increase proline synthesis and enhance protein hydrolysis $[53,54]$. There were differences in proline content among the two wheat cultivars under applied concentration of PEG. Proline content in root and shoot of Gemmeiza-12 were 
higher than those of Misr-2. In barley, no relation could be detected between proline accumulation and salinity tolerance, instead it represents a symptom of susceptibility [55]. In Artemisia aucheri, proline level was higher in drought sensitive wheat cultivar than resistant one under non-stressful or stressful condition regardless the application of SA or not [4]. In potato, the highest rate of proline accumulation was observed in drought-sensitive genotype, where slight increase in proline accumulation was observed in drought-tolerant one [52]. Our and their data supported the theory that proline accumulation under drought is a sign of stress-induced plant injures.

When plants were subjected to nutrient medium with PEG and SA, proline concentration was increased especially in plant roots, it was higher than that of the control but lower than that of plants exposed to PEG only. Proline concentration in shoots of Misr-2 was not influenced under the influence of PEG and SA together. Proline accumulation was attributed to increase of P5CS activity due to SA application [4].

In plants, biosynthesis of proline from glutamic acid via P5C is the main route for proline accumulation under stressed conditions. This pathway is catalyzed by P5CS and P5CR. Expression of P5CS gene in Misr-2 shoots and roots was hardly detected under non-stress condition even with SA, while it was clearly detected in Gemmeiza-12. Also, proline content of Gemmeiza-12 shoots and roots was higher than that of Misr-2. There was a positive correlation between registered proline content and P5CS expressions as was reported by [52]. Germination and growth indicated that the cultivar (Misr-2) that was more resistant to drought, had lower concentration of proline and lower P5CS expression, the opposite was true for Gemmeiza-12 (drought sensitive cultivar). In other plant species (A. thaliana), P5CS and P5CR transcripts are correlated with the proline content in organs, except in roots where it was lower than that of shoots. The low proline content under P5CS transcripts levels in roots of both wheat cultivars may be due to export of proline via xylem from roots to shoots [56]. Also, under non-stress condition, the values of proline content were controlled by expression of proline degrading genes (ProDH and P5CDH) where they were lower in Gemmeiza-12 than those of Misr-2.

Under PEG stress, expression of P5CS in Misr-2 was lower than that of Gimaza-12. On the other side, expression of proline catabolic genes including PDH and P5CDH were higher in Misr-2 than that of Gemmeiza-12. Up-regulation of proline biosynthetic genes and repression of proline catabolic genes led to increase of proline content, in wheat cultivars, it was associated with increase total pigments and photosynthetic activity which led to increase soluble sugars and activities of CAT, APOX, GPOX and SOD due to increase in ROS content, and they were higher in Gemmeiza-12 than those of Misr-2. Accumulation of soluble sugars was associated with activation P5CS expression and led to accumulation of proline [43]. When proline was supplied exogenously, soluble sugars and other soluble substances were accumulated [57]. The current study indicated that the proposed role of proline accumulation in express of drought tolerance $[4,5]$ was debatable because proline accumulation and the expression of proline synthesizing genes of wheat sensitive cultivar were higher than those of drought resistant cultivar. Drought tolerance in wheat cultivars was proportional with expression of proline catabolism genes, where their expression was higher in drought tolerant cultivar than sensitive one. It seems that when proline accumulation is maximized under drought conditions, the genes responsible for proline degradation 
pathway (PDH and P5CDH) work to convert proline to glutamate [58]. In drought-tolerant potato genotype, expressions of PDH and P5CDH genes were higher than those of drought-sensitive genotype under the influence of severe drought stress [52]. Consequently, drought-tolerant potato genotype was accumulated proline lower than that of drought-sensitive genotype under PEG-induced drought stress. Then, low proline content in wheat and other plant species such as potato was resulted from low expression of proline synthesizing genes (P5CS and P5CR) and high expression of proline degrading genes [52]. Consequently, P5CS and P5CR genes down-regulation and PDH and P5CDH genes up-regulation may be essential prerequisite for drought-tolerant genotypes $[52,59]$. The obtained data confirm the opinion suggests that proline accumulation results as a symptom of stress injury rather than an indicator of stress tolerance within plant species [52]. Our data indicated that, expression of PDH and P5CDH obviously decreased when the expressions of proline synthesis genes (P5CS and P5CR) increased under drought conditions as was detected in Gemmeiza-12.

In both plant cultivars, expression of P5CS in plants treated with PEG and/or SA was higher than that of control. In Misr-2, while, stressed plants showed up-regulation of P5CS gene, further up-regulation of P5CS was detected in stressed plants treated with SA. Vice versa was detected in Gemmeiza-12. Proline accumulation under drought stress can be related to up and/or down-regulation of P5CS and PDH genes, respectively [59]. There was a positive correlation between the level of P5CR expression and SA-induced proline accumulation under drought condition. As was detected in our work, [4] found that P5CS activity was increased in parallel with proline accumulation levels under drought stress and more activity of P5CS was observed when drought stressed plants were pretreated with SA. As in Misr-2 cultivar, [5] reported that treatment drought stressed plants with SA enhanced proline synthesis-related genes (P5CS and P5CR) but no change could be detected in proline degradation-related genes (PDH and P5CDH).

Consequently, in Misr-2, proline content of plants treated with PEG and SA was as same as of that of control. Under the influence of SA, up-regulation of PDH and P5CDH genes in Misr-2 were clearly higher than those of Gemmeiza-12. Stimulation of PDH by SA without change in proline content was detected in other plant species [4].

\section{Abbreviations}

Salicylic acid (SA); polyethylene glycol 6000 (PEG); Glucose (Glu), fructose (Fru); sucrose (Suc); catalase (CAT), ascorbate peroxidase (APX); guaiacol peroxidase (POX); superoxide dismutase (SOD); pyrroline-5carboxylate synthetase (P5CS); P5C dehydrogenase (P5CDH); proline dehydrogenase (PDH); reactive oxygen species (ROS)

\section{Declarations}

\section{Acknowledgement:}

Authors would like to thank the people in charge of the Wheat Research Department, Field Crops Research Institute (FCRI) at Agricultural Research Centre, Giza, Egypt, as they provided them with the 
seeds of the two wheat cultivars (Misr-2 and Gemmeiza-12) to achieve our study.

\section{Authors' contributions:}

$\mathrm{NL}, \mathrm{AMH}, \mathrm{MI}$ and $\mathrm{JMS}$ proposed the idea. $\mathrm{NL}$ and $\mathrm{MI}$ designed the experimental work, and performed the experimental measurements. AMH analyzed and interpreted the data and wrote the manuscript. JMS participated with $\mathrm{AMH}$ in analyzing and interpretation of the data, performed the calculations and statistical analysis, revised the manuscript, checked and adjusted the plagiarism, and acted as a corresponding author. All authors drafted the manuscript, read and approved the final manuscript.

\section{Compliance with ethical standards:}

Competing interests: The authors whose names are listed in this manuscript certify that they have NO affiliations with or involvement in any organization or entity with any financial or non-financial interest in the subject matter or materials discussed in this manuscript.

\section{Plant guidelines statement:}

Experimental research and field studies on plant material comply with relevant local institutional, national and international guidelines, regulations and legislation.

\section{References}

1. Hasanuzzaman, M., Nahar, K., Alam, M., Roychowdhury, R. \& Fujita, M. Physiological, Biochemical, and Molecular Mechanisms of Heat Stress Tolerance in Plants. Int. J. Mol. Sci. 14(5), 9643-9684 (2013).

2. Loutfy, N. et al. Changes in the water status and osmotic solute contents in response to drought and salicylic acid treatments in four different cultivars of wheat (Triticum aestivum) J. Plant Res. 125, 173-184 (2011).

3. Boyer, J.S. Plant productivity and environment. Sci. 218(4571): 443-8 (1982)

4. Abbaspour, J. \& Ehsanpour A.A. Sequential expression of key genes in proline, glycine betaine and artemisinin biosynthesis of Artemisia aucheri Boiss using salicylic acid under in vitro osmotic stress. Biol. 75,1251-1263 (2020).

5. La, V.H. et al. Characterization of salicylic acid-mediated modulation of the drought stress responses: Reactive oxygen species, proline, and redox state in Brassica napus. Environ. Exp. Bot. 157, 1-10 (2019).

6. Anjum, S.A. et al. Drought induced changes in growth, osmolyte accumulation and antioxidant metabolism of three maize hybrids. Front Plant Sci 8, 69 (2017). 
7. Hassanein, A.M., Galal, A. \& Saad, G.K. Shoot culture as plant material to study gene expression under the influence of different regeneration pathways and stress conditions in Lycopersicon esculentum Mill. J. Environ. S. 4, 23-34 (2010).

8. Aldesuquy, H. \& Ghanem, H. Exogenous Salicylic Acid and trehalose ameliorate short term drought stress in wheat cultivars by up-regulating membrane characteristics and antioxidant defense system. J. Horti. 2, 139 (2015).

9. Abd El-Mageed, T.A., Semida, W.M., Mohamed, G.F. \& Rady, M.M. Combined effect of foliar-applied salicylic acid and deficit irrigation on physiological-anatomical responses, and yield of squash plants under saline soil. Sou. Afri. J. Bot. 106, 8-16 (2016).

10. Khan, M.I.R., Iqbal, N., Masood, A., Per, T.S. \& Khan N.A. Salicylic acid alleviates adverse effects of heat stress on photosynthesis through changes in proline production and ethylene formation. Plant Sig. Behav. 8, e26374 10.4161/psb.26374 (2013).

11. Rejeb, B.K. et al. Hydrogen peroxide produced by NADPH oxidases increases proline accumulation during salt or mannitol stress in Arabidopsis thaliana. New Phytol. 208, 1138-1148 (2015)

12. Hayat, S. et al. Role of proline under changing environments. Plant Sig. Beh. 7(11), 1456-1466 (2012)

13. Armengaud, P., Thiery, L., Buhot, N., Grenier-De March, G. \& Savouré A. Transcriptional regulation of proline biosynthesis in Medicago truncatula reveals developmental and environmental specific features. Physiol. Plant. 120, 442-50; PMID: 15032841; http://dx.doi. org/10.1111/j.00319317.2004.00251.x (2004).

14. Ribarits, A. et al. Two tobacco proline dehydrogenases are differentially regulated and play a role in early plant development. Planta. 225, 1313-24; PMID:17106685;http://dx.doi.org/10.1007/s00425006-0429-3 (2007).

15. Verbruggen, N., Hua, X.J., May, M. \& Van Montagu, M. Environmental and developmental signals modulate proline homeostasis: evidence for a negative transcriptional regulator. Proc Natl Acad Sci USA, 93:8787-91; PMID:8710950; http://dx.doi. org/10.1073/pnas.93. 16.8787 (1996).

16. Rai, M.K., Kalia, R.K., Singh, R., Gangola, M.P. \& Dhawan, A.K. Developing stress tolerant plants through in vitro selection - An overview of the recent progress. Env. Exp. Bot. 71, 89-98 (2011).

17. Hassanein, A.M., Azooz, M.M., Loutfy, N. \& Basiony, A. Assessment of genetic diversity and salt tolerance of ten faba bean cultivars in relation to seed germination, seedling growth and molecular approach. Phyton (Horn, Austria). 60, 11-20 (2020).

18. Hassanein, A.M. et al. Germination of jojoba (Simmondsia chinensis $L$ ) seeds under the influence of several conditions. J. Env. St. 8, 10-16 (2012).

19. Hellal, F.A., El-Shabrawi, H.M., Abd El-Hady, M., Khatab, I.A. \& El-Sayed, S.A.A. Influence of PEG induced drought stress on molecular and biochemical constituents and seedling growth of Egyptian barley cultivars. J Gen Engineer Biotech. 16(1), 203-212 (2018).

20. Hoagland, D.R. \& Arnon D.I. The water-culture method of growing plants without soil. California Agricultural Experiment Station. Circular, 347. 
21. Michael, B.E. \& Kaufmann, M.R. The Osmotic Potential of Polyethylene Glycol 6000. Plant Physiol., 51(5): 914-916. doi: 10.1104/pp.51.5.914 (1973).

22. Metzner, H., Rau, H. \& Senger, H. Untersuchungen zur Synchronisierbareit einzelner Pigment mangel Mutanten von Chlorella. Planta, 65, 186-194 (1965).

23. Aebi, H. Catalase in vitro. Methods Enzymol., 105: 121-126 (1984).

24. Zhang, X. Research methodology of crop physiology. China Agric. Pre., Beij. 208-211 (1992).

25. Nakano, Y. \& Asada, K. Hydrogen peroxide is scavenged by ascorbate-specific peroxidase in spinach chloroplasts. Plant Cell Physiol. 22(5), 867-880 (1981).

26. Giannopolitis, C.N. \& Ries, S.K. Superoxide dismutases: 1- Occurrance in higher plants. Plant Physiol. I (59), 309-314 (1977).

27. Bates, L.S., Waldren, R.P. \& Teare, I.D. Rapid determination of free proline for water-stress studies. Plant Soil. 39(1), 205-207 (1973).

28. Snedecor, G.W. \& Cochran, W.G. Statistical methods. (7th edition) lowa State University Press, Ames, lowa (1980).

29. Othmani, A., Sourour, A., Zoubeir, C. \& Ben Younes, M. Screening for PEG-induced drought stress tolerance in seedlings of durum wheat (Triticum durum Desf.) cultivars. Pak. J. Bot. 53(3), 823-832. DOI: 10.30848/PJB2021-3(5) (2021).

30. Cai, K. et al. Screening of Worldwide Barley Collection for Drought Tolerance: The Assessment of Various Physiological Measures as the Selection Criteria. Front. Plant Sci. 11, 1159. doi: 10.3389/fpls.2020.01159 (2020).

31. Avramova1, V. et al. Screening for drought tolerance of maize hybrids by 2 multi-scale analysis of root and shoot traits at the seedling stage. J.Exp. Bot. 67(8), DOI: 10.1093/jxb/erw055 (2016).

32. Idrissi, O. et al. Genetic variability for root and shoot traits in a lentil (Lens culinaris) recombinant inbred line population and their association with drought tolerance. Euph. 204, 693-709 (2015).

33. Bojorquez-Quintal, E. et al. Mechanisms of salt tolerance in habanero pepper plants (Capsicum chinense Jacq.): proline accumulation, ions dynamics and sodium root-shoot partition and compartmentation. Front. Plant Sci. 5, 605 (2014).

34. Ferreira Júnior, D.C., Gaion, L.A. \& Sousa Júnior, G.S. Drought-induced proline synthesis depends on root-to-shoot communication mediated by light perception. Acta Physiol.,Plant. 40, 15. https://doi.org/10.1007/s11738-017-2591-6 (2018)

35. Yamaguchi, M. \& Sharp R.E. Complexity and coordination of root growth at low water potentials: recent advances from transcriptomic and proteomic analyses. Plant Cell Environ. 33 (4): 590603(2010)

36. Ghobadi, M., Shayesteh, T., Mohammad-Eghbal, G., Gholam-Reza, M. \& Saeid, J. Antioxidant capacity, photosynthetic characteristics and water relations of sunflower (Helianthus annuus L.) cultivars in response to drought stress. Industrial Crops. 50: 29-38 (2013). 
37. Mansour, H.A., Salwa, E.M. \& David, A. Molecular studies for drought tolerance in some Egyptian wheat genotypes under different irrigation systems. Open Agri. 5, 280-290 (2020)

38. Ebaid, M., Ali, I.N., Sanaa, I.M., Barakat, M.N. \& Ibrahim, O.M. Agronomic and Physiological Evaluation of Egyptian Wheat Cultivars under Salinity Stress. Middle East J. Agric. Res., 8(4): 1361-1370 (2019).

39. Gadallah, M.A., Sanaa, I. M., Mabrook, Y.M., Amira, Y. A. \& Gouda M.A. Evaluation of Some Egyptian Bread Wheat (Triticum aestivum) Cultivars under Salinity Stress. Alex. Sci. Exch. J. 38(2), 260 (2017).

40. Farag, F.M., Awaad, H.A., Abdel-Hameed, I.M. \& Abdul-Hamid, M.I.E. Stability of grain yield in bread wheat genotypes under different environments. Zagazig J. Agric. Res. 46(6A), 1797-1807. DOI: 10.21608/zjar.2019.51874 (2019).

41. Abid, M. Physiological and biochemical changes during drought and recovery periods at tillering and jointing stages in wheat (Triticum aestivum L.) Sci. Rep. 8, 4615 | DOI:10.1038/s41598-018-21441-7 (2018).

42. Couée, I., Sulmon, C., Gouesbet, G. \& El Amrani, A. Involvement of soluble sugars in reactive oxygen species balance and responses to oxidative stress in plants. J. Exp. Botany, 57(3), 449-459. https://doi.org/10.1093/jxb/erj027 (2006).

43. Wang, X. et al. Osmolyte accumulation plays important roles in the drought priming induced tolerance to post-anthesis drought stress in winter wheat (Triticum aestivum L.). Env. Exp. Botany, 166, 103804 (2019).

44. Ahmed, C.B., Rouina, B.B., Sensoy, S., Boukhris, M. \& Abdallah, F.B. Changes in gas exchange, proline accumulation and antioxidative enzyme activities in three olive cultivars under contrasting water availability regimes. Environ. Exp. Bot., 67, 345-352 (2009).

45. Fu, J. \& Huang, B. Involvement of antioxidants and lipid peroxidation in the adaptation of two coolseason grasses to localized drought stress. Environ. Exp. Bot. 45, 105-114 (2001).

46. Agarwal, S. \& Pandey, V. Antioxidant enzyme responses to $\mathrm{NaCl}$ stress in Cassia angustifolia. Biol. Plant. 48, 555-560 (2004).

47. Wang, X., Vignjevic, M., Jiang, D., Jacobsen, S. \& Wollenweber, B. Improved tolerance to drought stress after anthesis due to priming before anthesis in wheat (Triticum aestivum L.) var. Vinjett. $J$. Exp. Bot. 65 (22), 6441-6456 (2014b).

48. Uchida, A., Jagendorf, A.T., Hibinom, T., Takabe, T. \& Takabe, T. Effects of hydrogen peroxide and nitric oxide on both salt and heat stress tolerance in rice. Plant Sci., 163, 515-523 (2002).

49. Abbaspour, J. \& Ehsanpour, A. The impact of salicylic acid on some physiological responses of Artemisia aucheri Boiss. Under in vitro drought stress. Acta. Agric. Slov. 107, 287-298. https://doi.org/10.14720/aas.2016.107.2.03 (2016a).

50. Abbaspour, J. \& Ehsanpour, A.A. Physiological targets of salicylic acid on Artemisia aucheri Boiss as a medicinal and aromatic plant grown under in vitro drought stress. Bot Stud, 57, 39. https://doi.org/10.1186/s40529-016-0154-6 (2016b). 
51. Durner, J. \& Klessig, D.F. Inhibition of ascorbate peroxidase by salicylic acid and 2,6dichloroisonicotinic acid, 2 inducers of plant defense responses. Proc. nat. Acad. Sci. USA 92, 11312-11316 (1995).

52. Liu, Y., Wang, L., Li, Y., Li, X. \& Zhang. J. Proline metabolism-related gene expression in four potato genotypes in response to drought stress. Biol. Plant. 63, 757-764. DOI: 10.32615/bp.2019.153 (2019).

53. Jiang, G. et al. Redox regulation of the NOR transcription factor is involved in the regulation of fruit ripening in tomato. Plant Physiol., 183(2): 671-685, https://doi.org/10.1104/pp.20.00070 (2020).

54. Tarabih, M. \& EL-Eryan, E. Glycine betaine and proline with thinning technique for resistance abiotic stress of Cristalina cactus pear. Pak. J. Biol. Sci., 23, 68-80 (2020).

55. Chen, Z., Cuin, T.A., Zhou, M., Twomey, A., Naidu, B.P. \& Shabala, S. Compatible solute accumulation and stress-mitigating effects in barley genotypes contrasting in their salt tolerance. J. Exp. Bot. 58, 4245-4255 (2007).

56. Yoshiba, Y. et al. Correlation between the induction of a gene for D1-pyrroline-5-carboxylate synthetase and the accumulation of proline in Arabidopsis thaliana under osmotic stress. Plant J., 7, 751-760 (1995).

57. Gadallah, M.A.A. Effects of proline and glycine betaine on Vicia faba responses to salt stress. Biol. Plant. 42, 249-57; http://dx.doi. org/10.1023/A:1002164719609 (1999).

58. Adamipour, N. et al. Metabolic and genes expression analyses involved in proline metabolism of two rose species under drought stress. Plant Physiol Biochem., 155, 105-113. doi: 10.1016/j.plaphy.2020.07.028 (2020).

59. Rajaeian, S., Ehsanpour, A., Javadi, M. \& Shojaee, B. Ethanolamine induced modification in glycine betaine and proline metabolism in Nicotiana rustica under salt stress. Biol. Plant. 61,797-800. https://doi.org/10.1007/s10535-017-0704-0 (2017).

\section{Figures}


(A)

(Shoot)

(P5CS)

(ProDH)

(P5CDH)

Actin

rRNA

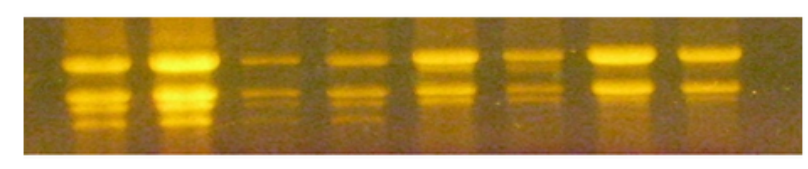

(Shoot)

(Root)

Con SA PEG PEG+SA Con SA PEG PEG+SA

(B)

(P5CS)

(ProDH)

(P5CDH)

Actin

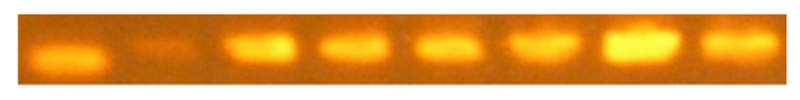

rRNA
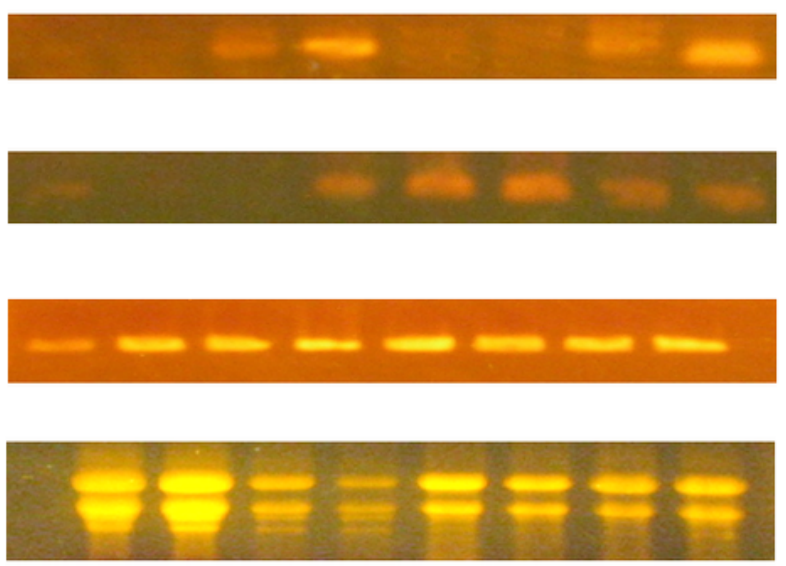

\section{Figure 1}

Northern blot analysis of the induction of proline responsible genes (P5CS, ProDH and P5CDH) by water deficit stress $(-0.4 \mathrm{Mpa})$ and salicylic acid $(0.5 \mathrm{mM})$ in shoots and roots of tolerant wheat cultivar (Misr-2; A) and sensitive wheat cultivar (Gemmeiza-12; B). Total RNA was isolated from shoot and root of two weeks old seedlings of both wheat cultivars, which were treated with different treatments as shown in this figure. Each lane was loaded with $5 \mu \mathrm{g}$ total RNA. The RNA was fractionated on $1 \%$ agarose gel. 


\section{Supplementary Files}

This is a list of supplementary files associated with this preprint. Click to download.

- supplementaryinformationfileofimages.pdf 